\title{
Analisis Pengaruh Potongan Harga, Paket Bonus, Pajangan dalam Toko dan Suasana Toko Terhadap Perilaku Pembelian Impulsif Pada Pelanggan Minimarket Indomaret Hybrid di Kota Semarang
}

\author{
Aria Ahmad Pradana, Retno Yustini Wahyuningdyah \\ email : retno_yustini@unika.ac.id \\ Fakultas Ekonomi dan Bisnis Unika Soegijapranata
}

\begin{abstract}
The purpose of this research is to analyze the effect of discount, bonus pack, in-store display, and store atmosphere towards customer's impulsive buying decision. The amount of sample in this research is 120. Sampling technique used in this research is purposive sampling and analyzed by multiple linear regression analysis using SPSS version 19. The result showed that discount has a significant and positive effect towards impulsive buying decision; bonus pack has a significant and positive effect towards impulsive buying decision; instore display has a significant and positive effect towards impulsive buying decision; and store atmosphere has a significant positive effect towards impulsive buying decision.
\end{abstract}

Keywords: Discount, Bonus Pack, In-Store Display, Store Atmosphere, Buying Decision, Impulsive Buying Decision

\section{PENDAHULUAN}

Konsumen Indonesia memiliki sepuluh karakter unik, yaitu berpikir jangka pendek, tidak terencana, gagap teknologi, orientasi pada konteks, suka merek luar negeri, religius, gengsi, kuat disubkultur (cenderung membedakan diri dari budaya yang lebih besar dimana mereka berada), kurang peduli terhadap lingkungan dan suka bersosialisasi (Swastha dan Irawan, 2003). Dari kesepuluh karakter unik yang ada menurut Boyd, Walker dan Laurreche (2000:145) sebagian besar keputusan pembelian adalah rendah dalam keterlibatan konsumen, konsumen tidak terlibat dalam pencarian informasi yang luas atau membuat evaluasi merek-merek alternatif yang detail, konsumen cenderung 
menerima informasi secara pasif. Pada dasarnya ada dua keputusan pembelian dengan keterlibatan rendah yaitu pembelian kelembamam (inertia buying) dan pembelian dorongan hati (impulse buying), peritel menggunakan strategi dan unsur pemasaran program yang berbeda pada kedua pembelian tersebut.

Menurut Utami (2010:70) sebagian besar konsumen Indonesia memiliki karakter tidak direncanakan (unplanned) dan lebih selektif dalam memilih model belanja. Mereka biasanya cenderung bertindak pada menit akhir (last minute) jika berbelanja, mereka sering menjadi impulse buyer. Sehubungan dengan karakteristik tersebut maka perilaku pembelian yang tidak direncanakan atau pembalian impulsif merupakan sesuatu alasan yang menarik bagi produsen maupun pengecer, karena merupakan pangsa pasar terbesar dalam pasar modern (Marketing/edisi khusus/II, 2007).

Hasil survey yang dilakukan AC Nielson yang menyatakan bahwa 85\% konsumen ritel modern di Indonesia cenderung berbelanja secara impulsif. Konsumen dalam membeli kebutuhannya tidak akan memikirkan suatu produk tertentu atau merek tertentu melainkan mereka langsung membeli karena ketertarikannya terhadap produk tersebut yang muncul secara tiba-tiba. Berdasarkan survey yang dilakukan oleh www.marketing.co.id, dalam periode enam tahun terakhir, dari tahun 2007-2012, jumlah gerai ritel modern di Indonesia mengalami pertumbuhan rata-rata $17,57 \%$ per tahun (Hidayati dan Seno, 2016).

Penelitian Fatimah (2017) dan Setyasih (2017) mengenai pengaruh potongan harga, paket bonus dan pajangan dalam toko terhadap pembelian impulsif, semua variabel berpengaruh positif dan signifikan terhadap pembelian impulsif. Sari dan Suryani (2014) penelitian mengenai pengaruh merchandising, promosi dan suasana toko terhadap pembelian impulasif, didapatkan hasil kegiatan merchandising, promosi dan penciptaan suasana toko berpengaruh positif dan signifikan terhadap pembelian impulsif. Manggiasih, Widiartono dan Prabawani (2015) dalam penelitianya mengenai discount, merchandising dan 
hedonic shopping motives terhadap perilaku pembelian impulsif, didapatkan hasil discount, merchandising dan hedonic shopping motives berpengaruh positif dan signifikan terhadap pembelian impulsif. Penelitian Hidayati dan Seno (2016) mengenai point of purchase, discount dan suasana toko terhadap pembelian impulsif didapatkan hasil semua variabel berpengaruh positif dan signifikan terhadap pembelian impulsif.

Asosiasi Pengusaha Ritel Indonesia tahun 2014 menyatakan setiap tahunnya gerai minimarket Indomaret terus mengalami peningkatan. Pada tahun 2009 berjumlah 3.892 unit dan pada tahun 2014 naik hampir 3 kali lipat yaitu sejumlah 10.600 unit. Hal tersebut merupakan respon dari PT. Indomarco Primatama yang mendirikan Waralaba Indomaret dengan visi “menjadi jaringan ritel yang unggul” dengan moto "mudah dan hemat”. (www.indomaret.co.id).

Tabel 1

Perkembangan Jumlah Gerai Minimarket Di Indonesia

\begin{tabular}{|c|c|c|c|c|c|c|}
\hline \multirow{2}{*}{ Minimarket } & \multicolumn{7}{|c|}{ Jumlah Gerai (Unit) } \\
\cline { 2 - 7 } & $\mathbf{2 0 0 9}$ & $\mathbf{2 0 1 0}$ & $\mathbf{2 0 1 1}$ & $\mathbf{2 0 1 2}$ & $\mathbf{2 0 1 3}$ & $\mathbf{2 0 1 4}$ \\
\hline Alfamart & 3,373 & 4,812 & 5,797 & 6,585 & 8,557 & 9,757 \\
\hline Indomaret & 3,892 & 4,955 & 6,006 & 7,242 & 8,814 & 10,600 \\
\hline
\end{tabular}

Sumber: Asosiasi Pengusaha Ritel Indonesia (2014)

Di Kota Semarang, berkembangnya minimarket modern terjadi karena berbagai hal diantaranya adalah karena penduduk yang semakin meningkat, dan seiring dengan pertumbuhan penduduk tersebut maka kebutuhan sehari-hari pun turut meningkat. Kota Semarang merupakan ibu Kota Provinsi Jawa Tengah. Bertambah jumlah minimarket modern. Adapun persebaran minimarket modern di Kota Semarang dapat dilihat melalui Tabel 2. 
Tabel 2

Jumlah Persebaran Minimarket Moderen Di Kota Semarang

\begin{tabular}{|c|c|c|c|c|c|}
\hline \multirow{2}{*}{ Kecamatan } & \multicolumn{5}{|c|}{ Tahun } \\
\cline { 2 - 6 } & $\mathbf{2 0 1 0}$ & $\mathbf{2 0 1 1}$ & $\mathbf{2 0 1 2}$ & $\mathbf{2 0 1 3}$ & $\mathbf{2 0 1 4}$ \\
\hline Mijen & 8 & 8 & 10 & 11 & 16 \\
\hline Gunungpati & 7 & 7 & 12 & 12 & 13 \\
\hline Banyumanik & 28 & 39 & 48 & 52 & 65 \\
\hline Gajah Mungkur & 15 & 15 & 21 & 22 & 23 \\
\hline Semarang Selatan & 18 & 14 & 29 & 32 & 39 \\
\hline Candisari & 8 & 10 & 17 & 17 & 21 \\
\hline Tembalang & 29 & 39 & 49 & 51 & 59 \\
\hline Genuk & 8 & 11 & 18 & 18 & 21 \\
\hline Gayamsari & 4 & 14 & 22 & 23 & 29 \\
\hline Semarang Timur & 11 & 13 & 21 & 22 & 25 \\
\hline Semarang Utara & 10 & 15 & 23 & 25 & 29 \\
\hline Semarang Tengah & 11 & 17 & 26 & 26 & 36 \\
\hline Semarang Barat & 23 & 31 & 49 & 51 & 65 \\
\hline Tugu & 6 & 8 & 9 & 11 & 13 \\
\hline Ngaliyan & 14 & 21 & 28 & 29 & 40 \\
\hline Total & 224 & 304 & 436 & 456 & 560 \\
\hline
\end{tabular}

Sumber : Dinas Perindustrian dan Perdagangan Kota Semarang, BPPT (2014)

Dari data persebaran jumlah minimarket di Kota Semarang pada tabel 2 peneliti memutuskan untuk fokus meneliti pada minimarket Indomaret Hybrid. Indomarket Hybrid masuk kategori convenience store memiliki variasi dan macam produk yang cukup banyak berupa makanan, minuman cepat saji dan menawarkan konsep toko yang berbeda dari pada indomaret biasa yaitu dengan adanya tambahan berupa tempat duduk, meja seperti konsep cafe (www.skyscrapercity.com)

Objek yang dipilih sebagai lokasi penelitian diantaranya Indomaret Pamularsih kecamatan Semarang Barat, Indomaret Ngesrep 1 kecamatan Banyumanik, Indomaret Sultan Agung kecamatan Candisari dan Indomaret Pandanaran kecamatan Semarang Selatan. Keempat Minimarket Indomaret ini menerapkan konsep hybrid dalam tokonya, pemilihan lokasi objek karena tempat yang strategis berada persis di pinggir jalan dan keempat Indomaret tersebut berada pada kecamatan yang saling berdekatan dan saling terhubung dengan batas 
wilayah. Pengujian yang dilakukan natinya akan mengetahui apakah konsumen pada keempat Indomaret tersebut cenderung lebih melakukan pembelian impulsif dibandingkan profil konsumen yang diteliti pada penelitian sebelumya.

Berdasarkan latar belakang yang dikemukakan sebelumnya maka penulis tertarik untuk melakukan penelitian mengenai “Analisis pengaruh Potongan harga, Paket bonus, Pajangan dalam toko dan Suasana toko terhadap perilaku Pembelian Impulsif pada Pelanggan Minimarket Indomaret Hybrid”

\section{Perumusan Masalah dan Tujuan Penelitian}

Dari latar belakang penelitian dapat ditarik beberapa pertanyaan penelitian sebagai berikut: Bagaimanakah ragam profil konsumen yang melakukan pembelian impulsif di empat minimarket Indomaret Hybrid ? Apakah potongan harga, paket bonus, pajangan dalam toko dan suasana toko berpengaruh secara parsial dan bersama-sama terhadap perilaku pembelian impulsif di empat minimarket Indomaret Hybrid di Semarang?

Tujuan penelitian ini untuk mengetahui: Profil konsumen yang melakukan pembelian impulsif di empat minimarket Indomaret Hybrid; Mengidentifikasi pengaruh potongan harga, paket bonus, pajangan dalam toko dan suasana toko secara parsial maupun bersama-sama terhadap perilaku pembelian impulsif.

\section{TINJAUAN PUSTAKA}

\section{Ritel Moderen}

Bisnis ritel merupakan segala kegiatan yang terkait dalam penjualan produk atau jasa secara langsung kepada konsumen akhir untuk kepentingan pribadi konsumen dan bukan penggunaan bisnis. Ritel menjadi perangkat aktivitasaktivitas bisnis yang menambah nilai produk dan layanan penjualan kepada konsumen untuk konsumsi perseorangan ataupun keluarga (Utami, 2010:5-12). Fungsi penting retail adalah sebagai berikut: menyediakan berbagai jenis produk dan jasa, memecah (breaking bulk), penyimpanan persediaaan, penyedia jasa. 


\section{Promosi Penjualan}

Promosi penjualan mengacu pada setiap insentif yang digunakan oleh pedagang besar dan ritel untuk memicu transaksi konsumen pada keputusan pembelian sebuah merek serta mendorong tenaga penjualan untuk secara agresif menjualnya. Promosi penjualan lebih berorientasi jangka pendek dan dapat mempengaruhi perilaku, bukan hanya sikap dan niat, tetapi juga perilaku karena menawarkan nilai lebih kepada pembeli dalam jangka pendek (Shimp, 2003:111112). Bentuk promosi penjualan untuk meningkatkan penjualan di toko antara lain: special display position, in-store display, in-store demonstration, point of sale material, price off promotion, price discound, sampling, coupons, refound of multiple purchase, bonus pack, on pack premiums, continuity coupons,on pack competitions dan merchandising stands (Utami, 2010:254).

\section{Potongan harga}

Diskon atau potongan harga adalah penyesuaian harga dasar untuk memberikan penghargaan pada pelanggan atas reaksi-reaksi tertentu, seperti pembayaran tagihan lebih awal, volume pembelian, dan pembelian diluar musim (Kotler dan Armstrong, 2001:485). Menurut Boyd, Walker dan Larrenche (2000:24) potongan harga adalah usaha mendorong anggota-anggota saluran atau pelanggan akhir untuk terlibat dalam perilaku spesifik dalam mendukung produk.

Bentuk-bentuk pada diskon atau potongan harga menurut Kotler dan Armstrong (2008:486) antara lain: Diskon kas (cash discount) adalah pengurangan harga pada pembeli yang membayar tagihan mereka tepat waktu. Diskon kuantitas (quantity discount) adalah pengurangan harga bagi pembeli yang membeli dalam volume besar. Diskon fungsional (functional discount) adalah diskon yang ditawarkan oleh penjual bagi anggota jalur distribusi yang melakukan fungsi-fungsi tertentu, seperti penjualan, pergudangan, dan pencatatan. Diskon musiman (seasonal discount) adalah pengurangan harga bagi pembeli yang membeli barang dagangan atau jasa di luar musim. 


\section{Paket Bonus}

Definisi Paket bonus adalah kuantitas produk ekstra yang diberikan konsumen dengan harga biasa. Nilai ektra yang ditawarkan kepada konsumen bersifat nyata, dapat digunakan untuk mempengaruhi ulang pemakai saat ini sehingga tidak beralih ke merek pesaing dan digunakan sebagai taktik untuk melawan pesaing yang agresif (Shimp, 2000:227). Paket bonus menawarkan konsumen sebuah muatan ekstra dari sebuah produk dengan harga normal (Belch \& Belch, 2009:553).

\section{Pajangan dalam toko}

Pajangan dalam toko (in-store display) adalah sebuah penarik awal yang bisa menarik pelanggan yang melintas dan masuk ke dalam toko (Amir, 2010 dalam Setyasih, 2017). Pajangan dalam toko adalah perlengkapan promosi pajangan yang berusaha menghasilkan lalu lintas konsumen, menonjolkan barang secara individual dan mendorong pembelian impulsif (Dunne dan Lusch, 2005:391). Pajangan merupakan unsur untuk merangsang perhatian dan ketertarikan konsumen atas produk atau toko dan menimbulkan keinginan untuk membeli atau berlangganan dengan toko melalui pendekatan visual langsung.

Dalam pengaturan pajangan dalam toko harus menyesuaikan perkiraan awal dengan dasar lima faktor (Utami, 2010:273-275) sebagai berikut: tingkat keuntungan barang pajangan, hasil inventaris terencana dan perbandingan persediaan, item barang yang mendorong pembelian impulsif, lokasi yang menarik dan bagian ritel yang akan ditekankan. Sedangkan hal-hal yang harus dipertimbangkan dalam memajang atau memajang ulang toko harus memenuhi empat tujuan: rancangan harus sesuai dengan kesan dan strategi, rancangan harus memengaruhi perilaku konsumen secara positif, rancangan harus mempertimbangkan biaya dan nilai, serta rancangan harus fleksibel. 


\section{Suasana Toko}

Suasana toko atau dapat disebut atmosphere toko adalah suatu desain lingkungan melalui komunikasi visual untuk merancang respon emosiaonal atau persepsi konsumen dan untuk mempengaruhi konsumen dalam membeli suatu produk (Berman dan Evans, 1995). Suasana toko adalah mendisain suatu lingkugan fisisk seperti arsitektur, tata letak, pencahayaan, warna, musik, temperatur dan penciuman untuk merangsang persepsi dan emosi dari konsumen sehingga perilaku belanja mereka terpengaruh (Levy dan Weitz, 2009:521 dalam Utami, 2010:52). Dari pengertian di atas dapat ditarik kesimpulan suasana toko bagi retil sangat penting untuk menunjukan tampilan fisik, dengan suasana toko yang menarik akan membangun citra dan minat beli konsumen. Elemen-elemen dari atmosphere toko dibagi ke dalam 4 dimensi (Berman dan Evans, 1995:550), yaitu: Eksterior, Interior Umum, Tata Letak Toko, dan Pajangan Interior (Point of Purchase).

\section{Perilaku Konsumen}

Perilaku konsumen merupakan sebuah studi tentang bagaimana induvidu, kelompok, dan organisasi memilih, membeli menggunkan dan bagaimana barang, jasa ide atau pengalaman untuk memuaskan kebutuhan dan keinginan mereka (Kotler \& Keller, 2009:166-174). Untuk mengetahui perilaku konsumen ada empat bidang yang menjadi pengaruh utama terhadap perilaku konsumen. Pengaruh budaya, pengaruh sosial, pengaruh psikologis dan pengaruh pribadi.

\section{Keputusan Pembelian}

Keputusan pembelian adalah sebuah tahapan dalam proses pengambilan keputusan pembeli dimana konsumen benar-benar membeli produk. Pengambilan keputusan konsumen pada dasarnya merupakan proses pemecahan masalah. Kebanyakan konsumen baik individu maupun pembeli organisasi melalui proses mental yang hampir sama dalam memutuskan produk dan merek apa yang akan di beli (Kotler dan Amstrong, 2001:226). Keputusan pembelian adalah proses pengambilan keputusan membeli produk disebabkan oleh perbedaan karakteristik 
pribadi dan pengaruh sosial, tetapi biasanya diikuti perilaku purna beli, dimana ada aspek ketidakpuasan dan aspek kepuasan yang nantinya akan mempengaruhi perilaku pembelian selanjutnya.

Proses pengambilan keputusan pembelian konsumen secara keseluruhan memiliki lima tahapan (Kotler dan Amstrong, 2001:222). Tahapan itu meliputi: pengenalan kebutuhan, pencarian informasi, mengevaluasi alternatif, mengambil keputusan. Dan evaluasi paska pembelian.

\section{Pembelian Tak Terencana (Unplanned Buying)}

Perilaku pembelian yang tidak terencanakan (unplanned buying) merupakan perilaku pembelian yang dilakukan dalam toko, dimana pembelian berbeda dari apa yang telah direncanakan konsumen pada saat mereka masuk ke dalam toko. Pembelian tak terencana bisa terjadi ketika seorang konsumen tidak familiar dengan tata ruang toko, dibawah tekanan waktu, atau seseorang yang teringat akan kebutuhan untuk membeli sebuah unit ketika melihat pada rak toko. Beberapa pembelian tidak terencana mungkin ditimbulkan oleh stimulasi atau rangsangan dalam toko, sedangkan yang lain mungkin tidak direncanakan sama sekali melainkan disebabkan perilaku yang terungkap (Utami, 2010:50-52).

Pembelian tak terencana dibagi menjadi dua kategori (Utami, 2010:52) yaitu: Reminder Purchases dan Impulse Purchases. Reminder purchases merupakan pembelian yang terjadi ketika konsumen melihat produk atau merek tertentu didalam toko dan teringat bahwa produk atau merek tersebut dibutuhkanya. Impulse Purchases. Pembelian impulsif terjadi ketika konsumen melihat produk atau merek tertentu, kemudian konsumen menjadi tertarik untuk mendapatkanya, biasanya karena ada rangsangan yang menarik dari toko tersebut.

\section{Pengertian Pembelian Impulsif}

Pembelian impulsif (impulse buying) adalah tindakan membeli yang dilakukan tanpa memiliki masalah sebelumnya atau maksut dan niat membeli yang terbentuk sebelum memasuki toko (Mowen dan Minor, 2001:65). Pembelian 
impulsif merupakan keputusan emosional atau menurut desakan hati. Pembelian impulsif merupakan proses pembelian dengan keterlibatan rendah, dimana konsumen memutuskan membeli merek yang berbeda sesuai dengan dorongan hatinya meskipun merek tersebut sudah akrab bagi mereka melalui eksposur pasif atau iklan dan informasi lain. Konsumen mengubah motivasi tersebut bukan karena tidak terpuaskan tetapi karena hasrat untuk mencari perubahan dan variasi (Schiffman dan Kanuk, 2004; Boyd, Walker dan Larrenche, 2000:131).

Pembelian impulsif lebih banyak terdapat pada barang yang diinginkan untuk dibeli, dan kebanyakan barang tersebut tidak diperlukan oleh konsumen. Pembelian impulsif terjadi ketika konsumen tiba-tiba mengalami keinginan yang kuat kukuh untuk membeli sesuatu secepatnya. Pembelian impulsif juga cenderung dilakukan dengan mengabaikan pertimbangan atas konsekuensinya (Utami, 2010:67).

Terdapat empat tipe pembelian impulsif Menurut Utami (2010:68) yaitu Impuls murni (Pure impulse), Impuls pengingat (Reminder impulse), Impuls saran (Suggestion impulse), dan Impuls Terencana (Planned Impulse). Terdapat tiga perspektif yang digunakan untuk menjelaskan munculnya perilaku pembelian impulsif (Utami, 2010:68). Karakteristik tersebut dijelaskan sebagai berikut: karakteristik produk, karakteristik konsumen dan karakteristik pemasaran.

\section{Penelitian Terdahulu}

Tabel 3

Penelitian Terdahulu

\begin{tabular}{|c|c|c|c|c|c|c|}
\hline No & $\begin{array}{c}\text { Judul, } \\
\text { peneliti } \\
\text { dan tahun }\end{array}$ & $\begin{array}{c}\text { Lokasi } \\
\text { peneitia } \\
\mathbf{n}\end{array}$ & $\begin{array}{c}\text { Populasi, } \\
\text { sampel dan } \\
\text { tehnik sampel }\end{array}$ & Variabel & $\begin{array}{l}\text { Meto } \\
\text { de } \\
\text { Anali } \\
\text { sis }\end{array}$ & Hasil Penelitian \\
\hline 1 & $\begin{array}{l}\text { Pengaruh } \\
\text { Price } \\
\text { discount, } \\
\text { Bonus } \\
\text { pack dan } \\
\text { In-Store } \\
\text { display } \\
\text { terhadap } \\
\text { keputusan } \\
\text { Impulse } \\
\text { buying }\end{array}$ & $\begin{array}{l}\text { Studi } \\
\text { kasus } \\
\text { pada } \\
\text { Janu } \\
\text { Putra } \\
\text { Swalaya } \\
\text { n di } \\
\text { Yogyak } \\
\text { arta }\end{array}$ & $\begin{array}{l}\text { Populasi dalam } \\
\text { penelitian ini } \\
\text { adalah seluruh } \\
\text { konsumen } \\
\text { yang melakuan } \\
\text { pembelian di } \\
\text { Janu Putra } \\
\text { Swalayan di } \\
\text { Yogyakarta. } \\
\text { Jumlah sampel } \\
85 \text { responden. }\end{array}$ & \begin{tabular}{ll}
\multicolumn{2}{l}{ Independe } \\
nt (X): \\
1. $\quad$ Poton \\
gan \\
Harg \\
a, \\
(X1) \\
2. Paket \\
Bonu \\
s(X2) \\
3. Pajan
\end{tabular} & $\begin{array}{c}\text { Regre } \\
\text { si } \\
\text { Linier } \\
\text { Berga } \\
\text { nda }\end{array}$ & $\begin{array}{l}\text { Variabel potongan harga } \\
\text { berpengaruh positif dan } \\
\text { signifikan terhadap } \\
\text { keputusan dengan } \\
\text { koefisien regresi } 0,196 \text { dan } \\
\text { nilai sig sebesar } 0,040 . \\
\text { Variabel paket bonus } \\
\text { berpengaruh positif dan } \\
\text { signifikan terhadap } \\
\text { keputusan pembelian } \\
\text { impulsif dengan koefisien }\end{array}$ \\
\hline
\end{tabular}




\begin{tabular}{|c|c|c|c|c|c|c|}
\hline No & $\begin{array}{c}\text { Judul, } \\
\text { peneliti } \\
\text { dan tahun }\end{array}$ & $\begin{array}{c}\text { Lokasi } \\
\text { peneitia } \\
\mathbf{n}\end{array}$ & $\begin{array}{c}\text { Populasi, } \\
\text { sampel dan } \\
\text { tehnik sampel }\end{array}$ & Variabel & $\begin{array}{l}\text { Meto } \\
\text { de } \\
\text { Anali } \\
\text { sis }\end{array}$ & Hasil Penelitian \\
\hline & $\begin{array}{l}\text { Meilani } \\
\text { Husnul } \\
\text { Fatimah } \\
\text { (2017) }\end{array}$ & & $\begin{array}{l}\text { Teknik } \\
\text { pengambilan } \\
\text { sampel non } \\
\text { probability } \\
\text { sampling yaitu } \\
\text { dengan } \\
\text { accidental } \\
\text { sampling. }\end{array}$ & $\begin{array}{ll} & \text { gan } \\
& \text { dala } \\
& \text { m } \\
& \text { toko } \\
& \text { (X3) } \\
\text { Dependen } \\
\text { t: } & \\
\text { 4. } & \text { Pemb } \\
& \text { elian } \\
& \text { impul } \\
& \text { sif } \\
& \text { (Y) }\end{array}$ & & $\begin{array}{l}\text { regresi 0,206 dan nilai sig } \\
\text { sebesar 0,031. } \\
\text { Variabel pajangan dalam } \\
\text { toko berpengaruh positif } \\
\text { dan signifikan terhadap } \\
\text { keputusan pembelian } \\
\text { impulsif dengan koefisien } \\
\text { regresi 0,244 dan nilai sig } \\
\text { sebesar 0,041. } \\
\text { Sementara itu variabel } \\
\text { potongan harga, paket } \\
\text { bonus dan pajangan dalam } \\
\text { toko berpengaruh terhadap } \\
\text { keputusan pembelian } \\
\text { impulsif sebesar } 44,5 \% \text {. }\end{array}$ \\
\hline 2 & $\begin{array}{l}\text { Analisa } \\
\text { pengaruh } \\
\text { Price } \\
\text { discount, } \\
\text { Bonus } \\
\text { pack, dan } \\
\text { In-store } \\
\text { display } \\
\text { terhadap } \\
\text { keputuhan } \\
\text { Impulse } \\
\text { buying } \\
\text { behavior } \\
\text { konsumen } \\
\text { Diah Arif } \\
\text { Setyasih } \\
\text { (2017) }\end{array}$ & $\begin{array}{l}\text { Studi } \\
\text { Kasus } \\
\text { pada } \\
\text { Swalaya } \\
\text { n } \\
\text { Kemban } \\
\text { g Mas } \\
\text { Grabag } \\
\text { Di Kota } \\
\text { Magela } \\
\text { ng }\end{array}$ & $\begin{array}{l}\text { Populasi dalam } \\
\text { penelitian ini } \\
\text { semua } \\
\text { konsumen } \\
\text { swalayan } \\
\text { Kembang Mas } \\
\text { Grabag } \\
\text { Magelang. } \\
\text { Jumlah sampel } \\
100 \text { responden } \\
\text { Teknik } \\
\text { pengambilan } \\
\text { sampel Non } \\
\text { probability } \\
\text { sampling }\end{array}$ & $\begin{array}{ll}\text { Independe } \\
\text { nt }(\mathrm{X}) \text { : } \\
\text { 1. } & \text { Poton } \\
& \text { gan } \\
& \text { harga } \\
& , \\
& \text { (X1) } \\
\text { 2. } & \text { Paket } \\
& \text { Bonu } \\
& \text { s } \\
& \text { (X2) } \\
\text { 3. } & \text { Pajan } \\
& \text { gan } \\
& \text { dala } \\
& \text { m } \\
& \text { toko } \\
& \text { (X3) } \\
\text { Dependen } \\
\text { t : } \\
\text { 4. } & \text { Pemb } \\
& \text { elian } \\
& \text { impul } \\
& \text { sif } \\
& \text { (Y) }\end{array}$ & $\begin{array}{c}\text { Regre } \\
\text { si } \\
\text { Linier } \\
\text { Berga } \\
\text { nda }\end{array}$ & $\begin{array}{l}\text { Variabel potongan harga } \\
\text { berpengaruh positif dan } \\
\text { signifikan terhadap } \\
\text { keputusan pembelian } \\
\text { impulsif dengan koefisien } \\
\text { regresi 0,166 dan nilai sig } \\
\text { sebesar 0,008. } \\
\text { Variabel paket bonus } \\
\text { berpengaruh positif dan } \\
\text { signifikan terhadap } \\
\text { keputusan pembelian } \\
\text { impulsif dengan koefisien } \\
\text { regresi 0,127 dan nilai sig } \\
\text { sebesar 0,026. } \\
\text { Variabel pajangan dalam } \\
\text { toko berpengaruh positif } \\
\text { dan signifikan terhadap } \\
\text { keputusan pembelian } \\
\text { impulsif dengan koefisien } \\
\text { regresi 0,653 dan nilai sig } \\
\text { sebesar 0,000. } \\
\text { Sementara itu variabel } \\
\text { potongan harga, paket } \\
\text { bonus dan pajangan dalam } \\
\text { toko berpengaruh terhadap } \\
\text { keputusan pembelian } \\
\text { impulsif sebesar 68,2\%. }\end{array}$ \\
\hline 3 & $\begin{array}{l}\text { Pengaruh } \\
\text { Merchandi } \\
\text { sing, } \\
\text { Promosi } \\
\text { dan } \\
\text { Suasana } \\
\text { toko }\end{array}$ & $\begin{array}{l}\text { Studi } \\
\text { kasus } \\
\text { Tiara } \\
\text { Dewata } \\
\text { Superm } \\
\text { arket } \\
\text { Denpas }\end{array}$ & $\begin{array}{l}\text { Populasi dalam } \\
\text { penelitian ini } \\
\text { seluruh } \\
\text { pelanggan } \\
\text { Tiara Dewata } \\
\text { Supermarket } \\
\text { Denpasar. }\end{array}$ & $\begin{array}{l}\text { Independe } \\
\text { nt }(\mathrm{X}) \text { : } \\
\text { 1. } \quad \text { Merc } \\
\quad \text { handi } \\
\quad \text { sing } \\
\quad \text { (X1) } \\
\text { 2. } \quad \text { Prom }\end{array}$ & $\begin{array}{c}\text { Regre } \\
\text { si } \\
\text { Linier } \\
\text { Berga } \\
\text { nda }\end{array}$ & $\begin{array}{l}\text { Variabel merchandising } \\
\text { berpengaruh positif dan } \\
\text { signifikan terhadap } \\
\text { keputusan pembelian } \\
\text { impulsif dengan koefisien } \\
\text { regresi } 0,286 \text { dan nilai sig } \\
\text { sebesar } 0,002 \text {. }\end{array}$ \\
\hline
\end{tabular}




\begin{tabular}{|c|c|c|c|c|c|c|}
\hline No & $\begin{array}{c}\text { Judul, } \\
\text { peneliti } \\
\text { dan tahun }\end{array}$ & $\begin{array}{c}\text { Lokasi } \\
\text { peneitia } \\
\mathbf{n}\end{array}$ & $\begin{array}{c}\text { Populasi, } \\
\text { sampel dan } \\
\text { tehnik sampel }\end{array}$ & Variabel & $\begin{array}{l}\text { Meto } \\
\text { de } \\
\text { Anali } \\
\text { sis } \\
\end{array}$ & Hasil Penelitian \\
\hline & $\begin{array}{l}\text { terhadap } \\
\text { Impulse } \\
\text { buying } \\
\text { Dewa Ayu } \\
\text { Taman } \\
\text { Sari, Alit } \\
\text { Suryani } \\
\text { (2014) }\end{array}$ & ar & $\begin{array}{l}\text { Jumlah sampel } \\
\text { yang } \\
\text { digunakan } \\
\text { sebesar } 114 \\
\text { responden } \\
\text { Dewata } \\
\text { Supermarket } \\
\text { Denpasar } \\
\text { Teknik } \\
\text { pengambilan } \\
\text { sampel } \\
\text { purposive } \\
\text { sampling }\end{array}$ & $\begin{array}{ll} & \text { osi } \\
& \text { (X2) } \\
\text { 3. } & \text { Suasa } \\
& \text { na } \\
& \text { toko } \\
& \text { (X3) } \\
\text { Dependen } \\
\mathrm{t}: & \\
4 . & \text { Pemb } \\
& \text { elian } \\
& \text { impul } \\
& \text { sif } \\
& \text { (Y) }\end{array}$ & & $\begin{array}{l}\text { Variabel promosi } \\
\text { berpengaruh positif dan } \\
\text { signifikan terhadap } \\
\text { keputusan pembelian } \\
\text { impulsif dengan koefisien } \\
\text { regresi 0,330 dan nilai sig } \\
\text { sebesar 0,001. } \\
\text { Variabel suasana toko } \\
\text { berpengaruh positif dan } \\
\text { signifikan terhadap } \\
\text { keputusan pembelian } \\
\text { impulsif dengan koefisien } \\
\text { regresi 0,258 dan nilai sig } \\
\text { sebesar 0,010. } \\
\text { Sementara itu variabel } \\
\text { merchandising, promosi } \\
\text { dan suasana toko } \\
\text { berpengaruh terhadap } \\
\text { keputusan pembelian } \\
\text { impulsif sebesar 62,4\%. }\end{array}$ \\
\hline 4 & $\begin{array}{l}\text { Pengaruh } \\
\text { Discount, } \\
\text { Merchandi } \\
\text { sing, dan } \\
\text { Hedonic } \\
\text { shopping } \\
\text { motives } \\
\text { terhadap } \\
\text { perilaku } \\
\text { Impulse } \\
\text { buying } \\
\text { Febrisa } \\
\text { Pawestri } \\
\text { Manggiasi } \\
\text { h,Widiarto } \\
\text { no, Bulan } \\
\text { Prabawani } \\
\text { (2015) }\end{array}$ & $\begin{array}{l}\text { Studi } \\
\text { kasus } \\
\text { pada } \\
\text { Robinso } \\
\text { n } \\
\text { Depart } \\
\text { men } \\
\text { Store } \\
\text { Mal } \\
\text { Ciputra } \\
\text { Semara } \\
\text { ng }\end{array}$ & $\begin{array}{l}\text { Populasi dalam } \\
\text { penelitian ini } \\
\text { seluruh } \\
\text { konsumen } \\
\text { Robinson } \\
\text { Department } \\
\text { Store Mal } \\
\text { Ciputra } \\
\text { Semarang } \\
\text { yang } \\
\text { jumlahnya } \\
\text { tidak diketahui } \\
\text { secara pasti } \\
\text { (indefinite). } \\
\text { Jumlah sampel } \\
\text { 100 responden } \\
\text { Teknik } \\
\text { pengambilan } \\
\text { sampel } \\
\text { purposive } \\
\text { sampling }\end{array}$ & $\begin{array}{ll}\text { Independe } \\
\text { nt (X): } \\
\text { 1. } & \text { Disco } \\
& \text { unt } \\
& \text { (X1) } \\
\text { 2. } & \text { Merc } \\
& \text { handi } \\
& \text { sing } \\
& \text { (X2) } \\
\text { 3. } & \\
& \text { Hedo } \\
& \text { nic } \\
& \text { shopp } \\
& \text { ing } \\
& \text { motiv } \\
& \text { es } \\
& \text { (X3) } \\
\text { Dependen } \\
\text { t: } \\
\text { 4. } & \text { Pemb } \\
& \text { elian } \\
& \text { impul } \\
& \text { sif } \\
& \text { (Y) }\end{array}$ & $\begin{array}{c}\text { Regre } \\
\text { si } \\
\text { Linier } \\
\text { Berga } \\
\text { nda }\end{array}$ & $\begin{array}{l}\text { Variabel discount } \\
\text { berpengaruh positif dan } \\
\text { signifikan terhadap } \\
\text { keputusan pembelian } \\
\text { impulsif dengan koefisien } \\
\text { regresi 0,358 dan nilai sig } \\
\text { sebesar 0,000. } \\
\text { Variabel merchandising } \\
\text { berpengaruh positif dan } \\
\text { signifikan terhadap } \\
\text { keputusan pembelian } \\
\text { impulsif dengan koefisien } \\
\text { regresi 0,543 dan nilai sig } \\
\text { sebesar 0,000. } \\
\text { Variabel hedonic shopping } \\
\text { motives berpengaruh } \\
\text { positif dan signifikan } \\
\text { terhadap keputusan } \\
\text { pembelian impulsif dengan } \\
\text { koefisien regresi } 0,702 \text { dan } \\
\text { nilai sig sebesar 0,000. } \\
\text { Sementara itu variabel } \\
\text { discount, merchandising } \\
\text { dan hedonic shopping } \\
\text { motives berpengaruh } \\
\text { terhadap keputusan } \\
\text { pembelian impulsif sebesar } \\
\text { 48,5\%. }\end{array}$ \\
\hline 5 & Pengaruh & Studi & Populasi dalam & Independe & Regre & Variabel point of purchase \\
\hline
\end{tabular}




\begin{tabular}{|c|c|c|c|c|c|c|}
\hline No & $\begin{array}{c}\text { Judul, } \\
\text { peneliti } \\
\text { dan tahun }\end{array}$ & $\begin{array}{c}\text { Lokasi } \\
\text { peneitia } \\
\mathbf{n}\end{array}$ & $\begin{array}{c}\text { Populasi, } \\
\text { sampel dan } \\
\text { tehnik sampel }\end{array}$ & Variabel & $\begin{array}{l}\text { Meto } \\
\text { de } \\
\text { Anali } \\
\text { sis }\end{array}$ & Hasil Penelitian \\
\hline & $\begin{array}{l}\text { Point of } \\
\text { purchase, } \\
\text { Discount } \\
\text { dan Store } \\
\text { atmospher } \\
\text { e terhadap } \\
\text { Impulse } \\
\text { buying } \\
\text { Annisa } \\
\text { Hidayati, } \\
\text { Agus } \\
\text { Hermani } \\
\text { D. Seno } \\
\text { (2016) }\end{array}$ & $\begin{array}{l}\text { Kasus } \\
\text { pada } \\
\text { Konsum } \\
\text { en } \\
\text { Swalaya } \\
\text { n } \\
\text { Mutiara } \\
\text { Cahaya } \\
\text { Slawi }\end{array}$ & $\begin{array}{l}\text { penelitian ini } \\
\text { seluruh } \\
\text { konsumen } \\
\text { Swalayan } \\
\text { Mutiara } \\
\text { Cahaya Slawi } \\
\text { ang jumlahnya } \\
\text { tidak diketahui } \\
\text { secara pasti } \\
\text { (indefinite). } \\
\text { Sampel 100 } \\
\text { responden. } \\
\text { Teknik } \\
\text { pengambilan } \\
\text { sampel } \\
\text { accidental } \\
\text { sampling dan } \\
\text { purposive } \\
\text { sampling }\end{array}$ & $\begin{array}{ll}\text { nt } & \text { (X): } \\
\text { 1. } & \text { Point } \\
& \text { of } \\
& \text { purch } \\
& \text { ase } \\
& \text { (X1) } \\
\text { 2. } & \text { Disco } \\
& \text { unt } \\
& \text { (X2) } \\
\text { 3. } & \text { Suasa } \\
& \text { na } \\
& \text { toko } \\
& \text { (X3) } \\
\text { Dependen } \\
\text { t: } \\
\text { 4. } & \text { Pemb } \\
& \text { elian } \\
& \text { impul } \\
& \text { sif } \\
& \text { (Y) }\end{array}$ & $\begin{array}{c}\text { si } \\
\text { Linier } \\
\text { Berga } \\
\text { nda }\end{array}$ & $\begin{array}{l}\text { berpengaruh positif dan } \\
\text { signifikan terhadap } \\
\text { keputusan pembelian } \\
\text { impulsif dengan koefisien } \\
\text { regresi 0,381 dan nilai sig } \\
\text { sebesar 0,000 } \\
\text { Variabel discount } \\
\text { berpengaruh positif dan } \\
\text { signifikan terhadap } \\
\text { keputusan pembelian } \\
\text { impulsif dengan koefisien } \\
\text { regresi 0,289 dan nilai sig } \\
\text { sebesar 0,010 } \\
\text { Variabel suasana toko } \\
\text { berpengaruh positif dan } \\
\text { signifikan terhadap } \\
\text { keputusan pembelian } \\
\text { impulsif dengan koefisien } \\
\text { regresi 0,221 dan nilai sig } \\
\text { sebesar 0,000. } \\
\text { Sementara itu variabel } \\
\text { point of purchase, discount } \\
\text { dan suasana toko } \\
\text { berpengaruh terhadap } \\
\text { keputusan pembelian } \\
\text { impulsif sebesar 46,5\% }\end{array}$ \\
\hline
\end{tabular}

\section{Kerangka Pikir}

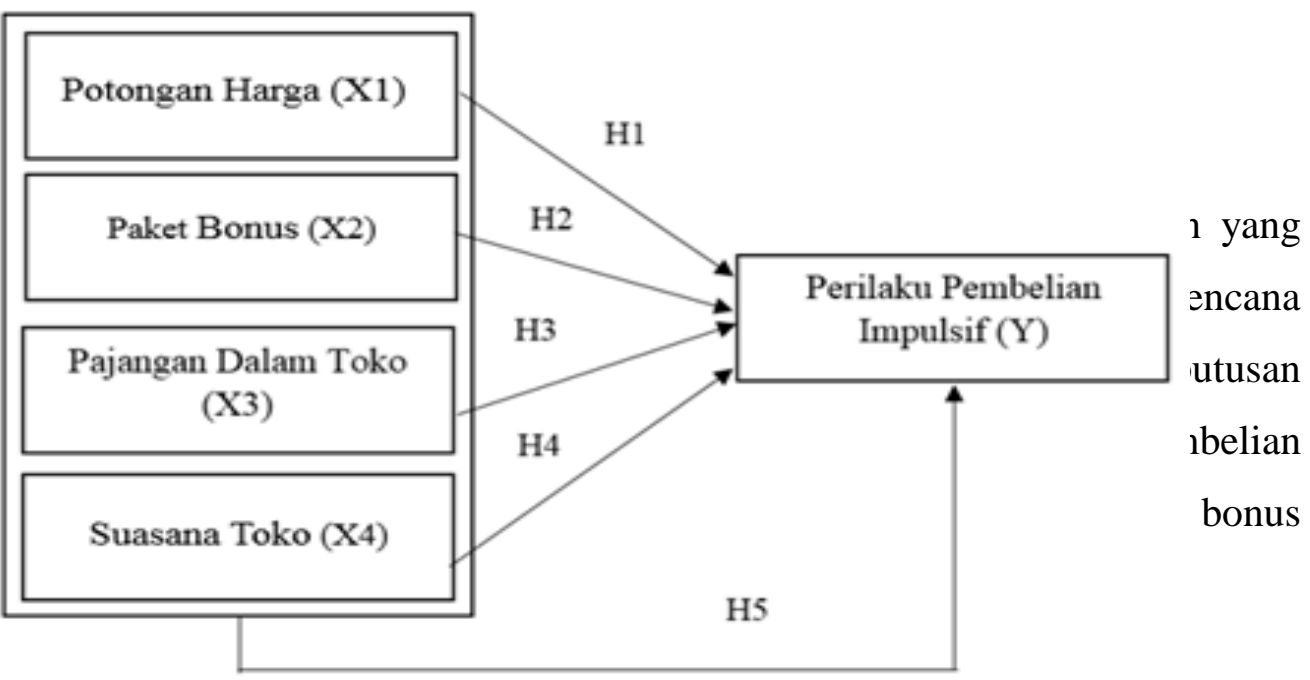

Hipotesis dalam penelitian ini adalah sebagai berikut : 
H1 : Potongan harga berpengaruh positif terhadap keputusan pembelian impulsif pada empat minimarket Indomaret Hybrid.

H2 : Paket bonus berpegaruh positif terhadap keputusan pembelian impulsif pada empat minimarket Indomaret Hybrid.

H3 : Pajangan dalam toko berpengaruh positif terhadap keputusan pembelian impulsif empat minimarket Indomaret Hybrid.

H4 : Suasana toko berpengaruh positif terhadap keputusan pembelian impulsif empat minimarket Indomaret Hybrid.

H5 : Potongan harga, paket bonus, pajangan dalam toko, suasana toko berpengaruh positif terhadap keputusan pembelian impulsif pada empat minimarket Indomaret Hybrid.

\section{Definisi Operasional}

Potongan harga produk di toko yang berkaitan dengan potongan harga tunai, pembelian jumlah minimum, merek khusus dan produk musiman yang menarik minat konsumen.

Paket bonus adalah penawaran sebuah muatan ekstra suatu produk di toko dengan harga normal disertai nilai tambah lebih, menarik perhatian dari pada produk lain dan pengaruh untuk pembelian yang lebih banyak.

Pajangan dalam toko adalah ketepatan penempatan produk yang mudah dilihat dan pada area display rak pajang, kemampuan penempatan pada dekat kasir dan pada area ujung rak, yang menarik perhatian konsumen dalam pembelian impulsif.

Suasana toko adalah desain lingkungan fisik seperti lingkungan sekitar pada area parkir, interior umum pencahayaan, warna, alokasi penyediaan ruangan bagi konsumen dan item promosi yang ada di toko untuk merancang respon dan persepsi konsumen dalam melakukan keputusan pembelian.

Perilaku pembelian impulsif adalah perilaku pembelian yang muncul pada saat berada di toko karena pengaruh emosi dari dalam diri konsumen ataupun faktor dari luar saat konsumen mempertimbangkan keputusan pembeliannya. 


\section{METODE PENELITIAN}

Peneliti mengambil lokasi penelitian pada empat minimarket Indomaret Hybrid di Kota Semarang. Populasi dalam penelitian ini yakni para pengunjung yang sedang berbelanja pada Indomaret Hybrid. Sampel ditentukan dengan metode Nonprobability sampling dengan teknik purposive sampling merupakan metode pemilihan sampel berdasarkan pertimbangan tertentu (Sugiyono, 2010;122). Adapun Kriteria responden yang diambil sebagai sampel adalah pelanggan yang berbelanja Indomaret Hybrid yang tidak merencanakan dari awal keputusan belanjanya atau terpengaruh oleh promosi penjualan dan suasana toko yang ada, sebelum ditetapkan sebagai sampel peneliti akan mengamati terlebih dahulu apakan responden melakukan pembelian impulsif karena di pengaruhi beberapa faktor di atas. Dari kelompok masyarakat yang menjadi pelanggan, profil pelanggan yang dipilih sebagai responden adalah masyarakat yang berumur minimal 18 tahun . Peneliti mengambil sampel minimun sebanyak 30 responden untuk setiap lokasi penelitian, terdapat empat lokasi penelitian sehingga total responden adalah 120 .

Data dalam penelitian ini berupa data primer yaitu data mentah diperoleh dari hasil penyebaran kuesioner pada sampel yang telah ditentukan. Teknik pengumpulan data dalam penelitian menggunakan kuesioner.

Kategori jawaban responden dapat dijelaskan sebagai berikut

$$
\begin{aligned}
1,00-1,80 & =\text { Sangat Tidak Setuju } \\
1,81-2,60 & =\text { Tidak Setuju } \\
2,61-3,40 & =\text { Netral } \\
3,41-4,20 & =\text { Setuju } \\
4,21-5,00 & =\text { Sangat Setuju }
\end{aligned}
$$

Tabel 4

Hasil Pengujian Validitas

\begin{tabular}{|c|c|c|c|c|}
\hline Variabel & $\begin{array}{c}\text { Indikator } \\
\text { Variabel }\end{array}$ & r hitung & $\mathbf{r}$ tabel & Keterangan \\
\hline \multirow{2}{*}{$\begin{array}{c}\text { Potongan } \\
\text { Harga }\end{array}$} & Indikator 1 & 0,529 & 0,178 & Valid \\
\cline { 2 - 5 } & Indikator 2 & 0,484 & 0,178 & Valid \\
\hline
\end{tabular}




\begin{tabular}{|c|c|c|c|c|}
\hline Variabel & $\begin{array}{c}\text { Indikator } \\
\text { Variabel }\end{array}$ & r hitung & r tabel & Keterangan \\
\hline & Indikator 3 & 0,462 & 0,178 & Valid \\
\hline & Indikator 4 & 0,357 & 0,178 & Valid \\
\hline \multirow[t]{3}{*}{ Paket Bonus } & Indikator 1 & 0,599 & 0,178 & Valid \\
\hline & Indikator 2 & 0,641 & 0,178 & Valid \\
\hline & Indikator 3 & 0,452 & 0,178 & Valid \\
\hline \multirow{4}{*}{$\begin{array}{c}\text { Pajangan } \\
\text { Dalam Toko }\end{array}$} & Indikator 1 & 0,503 & 0,178 & Valid \\
\hline & Indikator 2 & 0,528 & 0,178 & Valid \\
\hline & Indikator 3 & 0,346 & 0,178 & Valid \\
\hline & Indikator 4 & 0,349 & 0,178 & Valid \\
\hline \multirow{4}{*}{$\begin{array}{l}\text { Suasana } \\
\text { Toko }\end{array}$} & Indikator 1 & 0,492 & 0,178 & Valid \\
\hline & Indikator 2 & 0,529 & 0,178 & Valid \\
\hline & Indikator 3 & 0,417 & 0,178 & Valid \\
\hline & Indikator 4 & - & - & \\
\hline \multirow{4}{*}{$\begin{array}{l}\text { Pembelian } \\
\text { Impulsif }\end{array}$} & Indikator 1 & 0,433 & 0,178 & Valid \\
\hline & Indikator 2 & 0,500 & 0,178 & Valid \\
\hline & Indikator 3 & 0,325 & 0,178 & Valid \\
\hline & Indikator 4 & 0,395 & 0,178 & Valid \\
\hline
\end{tabular}

Sumber : Data Primer yang diolah 2017

Tabel 5

Hasil Pengujian Reliabilitas

\begin{tabular}{|l|l|c|c|}
\hline No & Variabel / Indikator & Alpha & Keterangan \\
\hline $\mathbf{1}$ & Potongan harga & 0,672 & Reliabel \\
\hline $\mathbf{2}$ & Paket Bonus & 0,732 & Reliabel \\
\hline $\mathbf{3}$ & Pajangan dalam toko & 0,647 & Reliabel \\
\hline $\mathbf{4}$ & Suasana toko & 0,667 & Reliabel \\
\hline $\mathbf{5}$ & Pembelian impulsif & 0,632 & Reliabel \\
\hline
\end{tabular}

Sumber : Data Primer yang diolah 2017

Analisis profil konsumen berupa tabel yang berisi mengenai jenis kelamin, usia, pekerjaan, pendidikan terakhir, status pernikahan, penghasilan perbulan, kepemilikan official account dan kepemilikan kartu berlangganan Indomaret kemudian akan dianalisis tabulasi silang (Crosstabulation). Analisis regresi linier 
berganda digunakan untuk meramalkan bagaimana keadaan variabel terikat, apabila dua atau lebih variabel bebas sebagai faktor prediktor dimanipulasi (Sugiyono, 2010:277).

\section{HASIL PENELITIAN}

\section{Gambaran Umum Indomaret Hybrid}

Indomaret merupakan jaringan minimarket yang menyediakan kebutuhan pokok dan kebutuhan sehari-hari dengan luas penjualan kurang lebih 200 meter persegi dan dikelola oleh PT. Indomarco Prismatama. Indomaret menawarkan beragam produk kebutuhan sehari-hari dengan kualitas yang dapat diandalkan, lengkap, harga hemat, dan lokasi toko yang mudah dijangkau karena penempatan lokasi gerai didasarkan pada motto "mudah dan hemat".

Indomarket Hybrid masuk kategori convenience store memiliki variasi dan macam produk yang cukup banyak berupa makanan, minuman cepat saji dan menawarkan konsep toko yang berbeda dari pada Indomaret biasa yaitu dengan adanya tambahan berupa tempat duduk, meja seperti konsep cafe.

\section{Gambaran Umum Responden}

Total responden sebanyak 120 orang, terdiri dari laki-laki sebanyak 58 orang atau sebesar 48,3\% dan perempuan sebanyak 62 orang atau sebesar 51,7\%. Hal ini berarti responden perempuan lebih banyak melakukan pembelian impulsif dibandingkan laki-laki. Sebagian besar pelanggan termasuk dalam usia produktif 18-38 tahun sebanyak 104 orang dengan presentase kumulatif 86,6\%, kemudian siasanya usia 39->45 tahun sebanyak 16 orang dengan presentase kumulatif 13,4\%. Hal ini berarti Indomaret Hybrid dalam meningkatkan jumlah pembelian impulsif sebaiknya menyasar pada usai produktif 18-38 tahun. Pekerjaan responden Indomaret Hybrid yang melakukan pembelian impulsif sebagian besar dengan pekerjaan yang memiliki waktu dan lokasi kerja yang fleksibel yaitu pegawai swasta dan pelajar atau mahasiswa sebanyak 102 orang dengan presentase kumulatif 85,0\%. Kemudian sisanya pegawai swasta, wiraswasta dan lainya sebanyak 18 orang dengan presentase kumulatif 15,0\%. Hal ini berarti 
penambahan area meja dan tempat duduk yang dilakukann Indomaret Hybrid sudah tepat untuk meningkatkan jumlah pelanggan dengan pekerjaan pegawai swasta dan pelajar atau mahasiswa.

Pengelompokan pendidikan terakhir responden Indomaret Hybrid yang melakukan pembelian impulsif sebagian besar pelanggan dengan pertimbangan (keterlibatan) rendah yaitu pendidikan terakhir SMA sebanyak 75 orang dengan presentase 62,5\%. Kemudian sisanya pelanggan dengan pertimbangan (keterlibatan) cukup tinggi yaitu pendidikan terakhir D1 atau D3, S1, dan S2 atau S3 sebanyak 45 orang dengan presentase kumulatif 37,5\%. Hal ini menunjukan bahwa sebagian besar pembelian impulsif terjadi jika pertimbangan (keterlibatan) rendah pada saat melakukan keputusan pembelian.

Penghasilan perbulan responden Indomaret Hybrid yang melakukan pembelian impulsif yaitu penghasilan 1 juta - 3 juta sebanyak 94 orang dengan presentase kumulatif 78,3\%, penghasilan 3 juta - 5 juta sebanyak 11 orang dengan presentase kumulatif 9,2\%, kemudian pelanggan yang tidak berpenghasilan 15 orang dengan presentase $12,5 \%$. Hal ini menunjukan sebagian besar pelanggan dengan penghasilan perbulan 1 juta - 3 juta lebih banyak melakukan pembelian impulsif.

Tabel 6

Pengelompokan Jenis Produk Impulsif

\begin{tabular}{|c|c|c|}
\hline Jenis Produk Impulsif & Jumlah & Presentase \\
\hline Alat Tulis & 1 & 0,8 \\
\hline Buah & 4 & 3,3 \\
\hline Ice Cream & 4 & 3,3 \\
\hline Makanan Instan & 6 & 5,0 \\
\hline Makanan Ringan & 32 & 26,7 \\
\hline Minuman Instan & 1 & 0,8 \\
\hline Minuman Kemasan & 25 & 20,8 \\
\hline Permen/Cokelat & 11 & 9,2 \\
\hline Produk Bayi & 3 & 2,5 \\
\hline Produk Elektronik & 1 & 0,8 \\
\hline Produk Kecantikan & 8 & 6,7 \\
\hline Produk Pembersih & 1 & 0,8 \\
\hline Produk Pembersih Rumah & 2 & 1,7 \\
\hline
\end{tabular}




\begin{tabular}{|c|c|c|}
\hline Jenis Produk Impulsif & Jumlah & Presentase \\
\hline Produk Perawatan Pria & 1 & 0,8 \\
\hline Pulsa Elektrik & 1 & 0,8 \\
\hline Roti & 15 & 12,5 \\
\hline Suplemen & 4 & 3,3 \\
\hline Total & 120 & 100,0 \\
\hline
\end{tabular}

Sumber : Data Primer yang diolah 2017

Tabel 7

Produk Impulsif Dan Jenis Kelamin

\begin{tabular}{|c|c|c|c|c|c|c|}
\hline \multirow{2}{*}{ Produk Impulsif } & \multicolumn{2}{|c|}{ Laki-Laki } & \multicolumn{2}{c|}{ Perempuan } & \multicolumn{2}{c|}{ Total } \\
\cline { 2 - 7 } & Jumlah & $\mathbf{\%}$ & Jumlah & $\mathbf{\%}$ & Jumlah & $\%$ \\
\hline ATK & 1 & 1,7 & 0 & 0 & 1 & 0,8 \\
\hline Buah & 3 & 5,2 & 1 & 1,6 & 4 & 3,3 \\
\hline Ice Cream & 0 & 0 & 4 & 6,5 & 4 & 3,3 \\
\hline Makanan Instan & 5 & 8,6 & 1 & 1,6 & 6 & 5,0 \\
\hline Makanan Ringan & 20 & 34,5 & 12 & 19,4 & 32 & 26,7 \\
\hline Minuman Instan & 1 & 1,7 & 0 & 0 & 1 & 0,8 \\
\hline Minuman Kemasan & 11 & 19,0 & 14 & 22,6 & 11 & 20,8 \\
\hline Permen/Cokelat & 3 & 5,2 & 8 & 12,9 & 3 & 9,2 \\
\hline Produk Bayi & 0 & 0 & 3 & 4,8 & 1 & 2,5 \\
\hline Produk Elektronik & 1 & 1,7 & 0 & 0 & 1 & 0,8 \\
\hline Produk Kecantikan & 0 & 0 & 8 & 12,9 & 8 & 6,7 \\
\hline Produk Pembersih & 1 & 1,7 & 0 & 0 & 8 & 0,8 \\
\hline Produk Pembersih Rumah & 0 & 0 & 2 & 3,2 & 1 & 1,7 \\
\hline Produk Perawatan Pria & 1 & 1,7 & 0 & 0 & 1 & 0,8 \\
\hline Pulsa Elektrik & 1 & 1,7 & 0 & 0 & 1 & 0,8 \\
\hline Roti & 8 & 13,8 & 7 & 11,3 & 15 & 12,5 \\
\hline Suplemen & 2 & 3,4 & 2 & 3,2 & 4 & 3,3 \\
\hline Total & 58 & 100 & 62 & 100 & 120 & 100 \\
\hline
\end{tabular}

Sumber : Data Primer yang diolah 2017

Berdasarkan tabel hasil pengolahan data melalui tabulasi silang jenis kelamin dengan produk impulsif, pelanggan laki-laki sebagian besar membeli produk impulsif makanan ringan 20 orang dengan presentase 34,5\%. Minuman kemasan 11 orang dengan presentase 19,0\% dan roti 8 orang dengan presentase 13,8\%. Sedangkan pelanggan perempuan sebagian besar membeli produk impulsif minuman kemasan 14 orang dengan presentase 22,6\%, makanan ringan 12 orang 
dengan presentase $19,4 \%$ dan roti 7 orang dengan presentase $11,3 \%$. Hal ini berarti produk impulsif yang paling sering dibeli sebagian besar pelanggan laki laki adalah makanan ringan sedangkan yang sering dibeli sebagian besar pelanggan perempuan adalah minuman kemasan.

\section{Gambaran Tanggapan Responden}

Tanggapan responden terhadap item kuesioner yang disampaikan adalah sebagaimana terlihat dalam tabel berikut.

Tabel 8

Tanggapan Responden

\begin{tabular}{|c|c|c|c|c|c|c|c|c|}
\hline \multirow[b]{2}{*}{ Item } & STS & TS & $\mathbf{N}$ & $\mathbf{S}$ & SS & \multirow[b]{2}{*}{$\Sigma \% F^{* S}$} & \multirow[b]{2}{*}{ Skor } & \multirow[b]{2}{*}{ Keterangan } \\
\hline & FxS & FxS & $\begin{array}{c}\mathbf{F x} \\
\mathrm{S}\end{array}$ & FxS & FxS & & & \\
\hline \multicolumn{9}{|l|}{$\begin{array}{c}\text { Potongan } \\
\text { Harga }\end{array}$} \\
\hline $\mathrm{X} 1.1$ & 0 & 12 & 78 & 316 & 45 & 451 & 3,76 & Setuju \\
\hline $\mathrm{X} 1.2$ & 1 & 12 & 93 & 300 & 35 & 441 & 3,68 & Setuju \\
\hline $\mathrm{X} 1.3$ & 1 & 4 & 72 & 244 & 160 & 481 & 4,01 & Setuju \\
\hline X1.4 & 1 & 10 & $\begin{array}{c}15 \\
3 \\
\end{array}$ & 208 & 55 & 427 & 3,56 & Setuju \\
\hline \multicolumn{7}{|c|}{ Rata-rata } & 3,75 & Setuju \\
\hline \multicolumn{9}{|c|}{ Paket Bonus } \\
\hline $\mathrm{X} 2.1$ & 0 & 4 & 69 & 304 & 95 & 472 & 3,93 & Setuju \\
\hline $\mathrm{X} 2.2$ & 0 & 6 & 72 & 304 & 85 & 467 & 3,89 & Setuju \\
\hline $\mathrm{X} 2.3$ & 0 & 12 & 72 & 252 & 135 & 471 & 3,93 & Setuju \\
\hline \multicolumn{7}{|c|}{ Rata-rata } & 3,92 & Setuju \\
\hline $\begin{array}{c}\text { Pajangan } \\
\text { dalam } \\
\text { toko }\end{array}$ & & & & & & & & \\
\hline
\end{tabular}




\begin{tabular}{|c|c|c|c|c|c|c|c|c|}
\hline \multirow[b]{2}{*}{ Item } & STS & TS & $\mathbf{N}$ & $\mathbf{S}$ & SS & \multirow[b]{2}{*}{$\Sigma \% \mathrm{~F}^{*} \mathrm{~S}$} & \multirow[b]{2}{*}{ Skor } & \multirow[b]{2}{*}{ Keterangan } \\
\hline & FxS & FxS & $\begin{array}{c}\mathbf{F x} \\
\mathrm{S}\end{array}$ & FxS & FxS & & & \\
\hline X3.1 & 0 & 8 & 78 & 312 & 60 & 458 & 3,82 & Setuju \\
\hline X3.2 & 1 & 8 & 90 & 272 & 85 & 456 & 3,80 & Setuju \\
\hline X3.3 & 0 & 4 & 57 & 220 & 220 & 501 & 4,18 & Setuju \\
\hline X3.4 & 0 & 10 & $\begin{array}{c}12 \\
3 \\
\end{array}$ & 268 & 35 & 436 & 3,63 & Setuju \\
\hline \multicolumn{7}{|c|}{ Rata-rata } & 3,86 & Setuju \\
\hline \multicolumn{9}{|l|}{$\begin{array}{l}\text { Suasana } \\
\text { toko }\end{array}$} \\
\hline $\mathrm{X} 4.1$ & 0 & 6 & 60 & 296 & 115 & 477 & 3.98 & Setuju \\
\hline $\mathrm{X} 4.2$ & 0 & 4 & 54 & 264 & 170 & 492 & 4.10 & Setuju \\
\hline $\mathrm{X} 4.3$ & 0 & 2 & 36 & 228 & 245 & 511 & 4.29 & Setuju \\
\hline $\mathrm{X} 4.4$ & 0 & 14 & $\begin{array}{c}18 \\
0\end{array}$ & 192 & 25 & 411 & 3.43 & Setuju \\
\hline \multicolumn{7}{|c|}{ Rata-rata } & 3.95 & Setuju \\
\hline \multicolumn{9}{|l|}{$\begin{array}{c}\text { Pembelian } \\
\text { Impulsif }\end{array}$} \\
\hline Y.1 & 0 & 4 & 96 & 276 & 85 & 461 & 3,84 & Setuju \\
\hline Y.2 & 0 & 8 & 51 & 320 & 95 & 474 & 3,95 & Setuju \\
\hline Y.3 & 0 & 4 & 78 & 300 & 85 & 467 & 3,89 & Setuju \\
\hline Y.4 & 0 & 4 & 57 & 272 & 155 & 488 & 4,07 & Setuju \\
\hline \multicolumn{7}{|c|}{ Rata-rata } & 3,94 & Setuju \\
\hline
\end{tabular}

Sumber : Data primer yang diolah 2017

\section{Analisis Regresi Berganda}

Selanjutnya data hasil pengumpulan data diolah dengan analisis regresi berganda. Beberapa hasil pengolahan data dapat dilihat pada tabel berikut:

Tabel 9

\section{Koefisien Regresi Berganda}

\begin{tabular}{|l|l|c|c|c|}
\hline \multirow{2}{*}{ Model } & \multicolumn{2}{|c|}{ Unstandardized Coefficients } & \multirow{2}{*}{ Sig. } \\
\cline { 2 - 4 } & B & Std. Error & Sig. \\
\hline \multirow{3}{*}{1} & (Constant) &, 269 & 1,028 &, 794 \\
\cline { 2 - 5 } & Potongan_harga_tot_x1 &, 331 &, 057 &, 000 \\
\cline { 2 - 5 } & Paket_bonus_tot_x2 &, 249 &, 068 &, 000 \\
\hline
\end{tabular}




\begin{tabular}{|l|l|c|c|c|}
\hline & Pajangan_dalam_toko_tot.x3 &, 245 &, 055 &, 000 \\
\cline { 2 - 4 } & Suasana_toko_totx4 &, 307 &, 068 &, 000 \\
\hline
\end{tabular}

a. Dependent Variable: Pembelian_impulsif_tot.y

Sumber : Data primer yang diolah 2017

Dari hasil data tabel apabila ditulis dengan persamaan regresi dalam bentuk unstandardized coefficient sebagai berikut:

$$
Y=0,269+0,331 X_{1}+0,249 X_{2}+0,245 X_{3}+0,307 X_{4}
$$

Keterangan:

$\mathrm{Y}=$ Pembelian Impulsif

$\mathrm{X}_{1}=$ Potongan Harga

$\mathrm{X}_{2}=$ Paket Bonus

$\mathrm{X}_{3}=$ Pajangan Dalam Toko

$\mathrm{X}_{4}=$ Suasana Toko

\section{Uji Hipotesis}

Dari hasil pengujian hipotesis baik secara parsial maupun bersama-sama semua hipotesis terbukti mempunyai pengaruh yang positif dan signifikan.

Tabel 10

Koefisien Uji Parsial (Uji t)

\begin{tabular}{|l|c|c|c|}
\hline \multicolumn{2}{|c|}{ Model } & t hitung & Sig. \\
\hline \multirow{4}{*}{1} & (Constant) &, 262 &, 794 \\
\cline { 2 - 4 } & Potongan_harga_tot.x1 & 5,762 &, 000 \\
\cline { 2 - 4 } & Paket_bonus_tot.x2 & 3,642 &, 000 \\
\cline { 2 - 4 } & Pajangan_dalam_toko_tot.x3 & 4,460 &, 000 \\
\cline { 2 - 4 } & Suasana_toko_tot.x4 & 4,488 &, 000 \\
\hline
\end{tabular}

a. Dependent Variable: Pembelian_impulsif_tot.y

Sumber : Data primer yang diolah 2017 
Tabel 11

Anova Uji Simultan (Uji F)

\begin{tabular}{|l|l|c|c|c|c|c|}
\hline \multicolumn{2}{|l|}{ Model } & $\begin{array}{c}\text { Sum of } \\
\text { Squares }\end{array}$ & Df & $\begin{array}{c}\text { Mean } \\
\text { Square }\end{array}$ & F & Sig. \\
\hline \multirow{3}{*}{1} & Regression & 272,921 & 4 & 68,230 & 59,634 &, $000^{\text {a }}$ \\
\cline { 2 - 7 } & Residual & 131,579 & 115 & 1,144 & & \\
\cline { 2 - 7 } & Total & 404,500 & 119 & & & \\
\hline
\end{tabular}

a. Predictors: (Constant), suasana_toko_totx4, pajangan_dalam_toko_tot.x3, Paket_bonus_tot_x2, Potongan_harga_tot_x1

b. Dependent Variable: pembelian_impulsif_tot.y

Sumber : Data primer yang diolah 2017

Tabel 11

\section{Koefisien Determinasi $\left(\mathbf{R}^{2}\right)$}

\begin{tabular}{|c|c|c|c|c|}
\hline Model & $\mathrm{R}$ & R Square & Adjusted R Square & $\begin{array}{c}\text { Std. Error of the } \\
\text { Estimate }\end{array}$ \\
\hline 1 &, $821^{\mathrm{a}}$ &, 675 &, 663 & 1,06965 \\
\hline
\end{tabular}

a. Predictors: (Constant), suasana_toko_totx4, pajangan_dalam_toko_tot.x3,

Paket_bonus_tot_x2, Potongan_harga_tot_x1

b. Dependent Variable: pembelian_impulsif_tot.y

Sumber : Data Primer, diolah 2017

Untuk mengetahui seberapa besar pengaruh variabel bebas terhadap variabel terikat secara bersama-sama, maka bisa dilihat dari adjusted $R$ square sebesar 0,675. Hal ini berarti bahwa variabel terikat yaitu pembelian impulsif pelanggan Indomaret Hybrid dipengaruhi sebesar $67,5 \%$ oleh variabel bebas yaitu $\left(\mathrm{X}_{1}\right)$ potongan harga, $\left(\mathrm{X}_{2}\right)$ paket bonus, $\left(\mathrm{X}_{3}\right)$ pajangan dalam toko, $\left(\mathrm{X}_{4}\right)$ suasana toko. Sedangkan terdapat faktor-faktor lain yang tidak diteliti dalam penelitian ini namun berpengaruh pada pembelian impulsif dengan nilai kontribusi adalah sebesar $(100 \%-67,5 \%)=32,5 \%$.

\section{KESIMPULAN}

Berdasarkan hasil penelitian tentang pengaruh Potongan Harga, Paket Bonus, Pajangan Dalam Toko dan Susasana Toko Terhadap Perilaku Pembelian Impulsif pada pelanggan Minimarket Indomaret Hybrid di Kota Semarang maka dapat disimpulkan beberapa hal sebagai berikut data profil responden diketahui 
bahwa sebagian besar pelanggan Minimarket Indomaret Hybrid yang melakukan pembelian impulsif adalah perempuan dengan jumlah 62 orang, usia antara 18-24 tahun, pekerjaan adalah pegawai swasta, pendidikan terakhir SMA sederajat, status pernikahan sudah menikah, penghasilan perbulan 2.000.000 - 3.000.000 perbulan dan jenis produk impulsif yang paling sering dibeli adalah makanan ringan.

Variabel Potongan Harga, Paket Bonus, Pajangan dalam Toko, dan Suasana Toko memiliki pengaruh positif dan signifikan secara parsial maupun bersama terhadap Perilaku Pembelian Impulsif pelanggan.

\section{Saran}

Berdasarkan dari hasil olah data yang diperoleh dari kesimpulankeimpulan penelitian yang telah dijelaskan sebelumnya, maka terdapat saran sebagai berikut: berdasarkan hasil penelitian yang melakukan pembelian impulsif adalah perempuan dengan usia 18-24 tahun, pekerjaan pegawai swasta dengan pendidikan terakhir SMA sederajat, status sudah menikah dengan penghasilan perbulan 2.000.000 - 3.000.000 perbulan. PT. Indomarco Prismatama perlu berfokus pada segmen pasar potensial perempuan (ibu rumah tangga) dengan mengadakan berbagai macam event pomosi penjualan, lebih meningkatkan jumlah pelanggan yang mempunyai member card (Indomaret Card). Dapat pula diletakan pamflet (point of purchase) disekitar area kasir mengenai keunggulan dan jenisjenis member card yang ada.

Secara keseluruhan diharapkan PT. Indomarco Prismatama terus melakukan promosi potongan harga atau paket bonus seperti makanan ringan, minuman kemasan, produk private label dan produk yang ada pada katalog mingguan diletakan pada sekitar area kasir yang mudah terlihat, melakukan bundling produk, lebih banyak melakukan Point of Purchase untuk setiap produk dan penyediaan area untuk konsumen lebih ditingkatkan kebersihan sekaligus kemudahan melihat pogram promosi yang sedang ditawarkan. Bagi penelitian selanjutnya disarankan untuk menambah variabel lain diluar variabel potongan 
harga, paket bonus, pajangan dalam toko dan suasana toko yang mempengaruhi pembelian impulsif karena variabel yang diteliti memiliki pengaruh terhadap pembelian impulsif sebesar 67,5\%, sedangkan 32,5\% dipengaruhi variabel lain yang tidak termasuk dalam penelitian ini.

Lampiran Kuesioner Tanggapan responden mengenai potongan harga, paket bonus, pajangan dalam toko dan suasana toko

\begin{tabular}{|l|l|l|l|l|l|l|}
\hline No & Pernyataan tentang potongan harga X1 & \multicolumn{3}{|c|}{ Jawaban } \\
\cline { 3 - 6 } & & STS & TS & N & S & SS \\
\hline 1. & $\begin{array}{l}\text { Saya membeli produk dari distributor } \\
\text { (Indofood, Mayora, Wingsfood dll) karena } \\
\text { terdapat potongan harga pada produknya }\end{array}$ & & & & & \\
\hline 2. & $\begin{array}{l}\text { Saya melakukan pembelian minimun dengan } \\
\text { nominal tertentu agar mendapatkan potongan } \\
\text { harga }\end{array}$ & & & & & \\
\hline 3. & $\begin{array}{l}\text { Saya membeli produk dengan “merek } \\
\text { khusus Indomaret” karena terdapat potongan } \\
\text { harga pada produknya }\end{array}$ & & & & & \\
\hline 4. & $\begin{array}{l}\text { Saya melakukan pembelian pada saat musim } \\
\text { tertentu karena terdapat potongan harga pada } \\
\text { produknya }\end{array}$ & & & & & \\
\hline
\end{tabular}

\begin{tabular}{|l|l|l|l|l|l|l|}
\hline No & Pernyataan tentang paket bonus X2 & \multicolumn{4}{|c|}{ Jawaban } \\
\cline { 3 - 6 } & & STS & TS & N & S & SS \\
\hline 1. & $\begin{array}{l}\text { Saya membeli produk dengan promosi paket } \\
\text { bonus karena memberikan manfaat lebih dari } \\
\text { pada produk biasa }\end{array}$ & & & & \\
\hline 2. & $\begin{array}{l}\text { Saya membeli produk dengan tambahan } \\
\text { paket bonus karena lebih menarik perhatian } \\
\text { dari pada produk sejenis tanpa paket bonus }\end{array}$ & & & & & \\
\hline 3. & $\begin{array}{l}\text { Saya akan melakukan pembelian lebih } \\
\text { banyak dari pada biasanya jika produk } \\
\text { tersebut terdapat paket bonus di dalamnya }\end{array}$ & & & & & \\
\hline
\end{tabular}

\begin{tabular}{|l|l|l|l|l|l|l|}
\hline No & Pernyataan tentang pajangan dalam toko & \multicolumn{5}{|c|}{ Jawaban } \\
\cline { 2 - 6 } & X3 & STS & TS & N & S & SS \\
\hline 1. & $\begin{array}{l}\text { Saya membeli produk yang berada pada rak } \\
\text { bagian atas dari pada produk yang berada di } \\
\text { bagian bawah. }\end{array}$ & & & & \\
\hline 2. & $\begin{array}{l}\text { Saya membeli produk karena kemudahan } \\
\text { melihat dan mencari produk di rak pajang. }\end{array}$ & & & & & \\
\hline
\end{tabular}




\begin{tabular}{|l|l|l|l|l|l|l|}
\hline 3. & $\begin{array}{l}\text { Saya membeli produk yang berada di sekitar } \\
\text { area kasir dan dekat pintu masuk. }\end{array}$ & & & & \\
\hline 4. & $\begin{array}{l}\text { Saya membeli produk yang berada pada } \\
\text { ujung rak pajang karena fleksibel } \\
\text { penempatanya dan mendorong minat beli }\end{array}$ & & & & \\
\hline
\end{tabular}

\begin{tabular}{|l|l|l|l|l|l|l|}
\hline No & Pernyataan tentang suasana toko X4 & \multicolumn{3}{|c|}{ Jawaban } \\
\cline { 3 - 6 } & & STS & TS & N & S & SS \\
\hline 1. & $\begin{array}{l}\text { Saya memilih membeli produk di Indomaret } \\
\text { karena ketersediaan area parkir }\end{array}$ & & & & \\
\hline 2. & $\begin{array}{l}\text { Saya memilih membeli produk di Indomaret } \\
\text { karena terpengaruh oleh interior dalam toko } \\
\text { (warna, pencahayaan, dan suhu udara dalam } \\
\text { ruangan) }\end{array}$ & & & & & \\
\hline 3. & $\begin{array}{l}\text { Saya memilih membeli produk di Indomaret } \\
\text { karena memiliki area ruangan yang } \\
\text { meningkatkan kenyamanan konsumen (area } \\
\text { duduk di depan dan di dalam toko) }\end{array}$ & & & & & \\
\hline 4. & $\begin{array}{l}\text { Saya memilih membeli produk di Indomaret } \\
\text { karena terpengaruh pajangan interior (poster } \\
\text { dan display barang pada hari khusus) }\end{array}$ & & & & & \\
\hline
\end{tabular}

\begin{tabular}{|l|l|l|l|l|l|l|}
\hline No & Pernyataan tentang pembelian impulsif Y & \multicolumn{5}{|c|}{ Jawaban } \\
\cline { 3 - 6 } & & STS & TS & N & S & SS \\
\hline 1. & $\begin{array}{l}\text { Saya membeli produk di Indomaret Hybrid } \\
\text { karena terpengaruh promosi potongan harga. }\end{array}$ & & & & & \\
\hline 2. & $\begin{array}{l}\text { Saya membeli produk di Indomaret Hybrid } \\
\text { karena terpengaruh promosi paket bonus. }\end{array}$ & & & & & \\
\hline 3. & $\begin{array}{l}\text { Saya membeli produk di Indomaret Hybrid } \\
\text { karena terpengaruh promosi pajangan dalam } \\
\text { toko. }\end{array}$ & & & & & \\
\hline 4. & $\begin{array}{l}\text { Saya memutuskan membeli produk di } \\
\text { Indomaret Hybrid karena terpengaruh } \\
\text { suasana toko. }\end{array}$ & & & & & \\
\hline
\end{tabular}




\section{DAFTAR PUSTAKA}

Belch, George E. dan Michael A. Belch (2009). Advertising and Promotion : An. Integrated Marketing Communication Perpective (8th Ed). New York: McGrew-Hill Irwin

Boyd, Oliver .C, Walker, Jr dan Jean C. Larrenche. (2000). Manajemen Pemasaran :Suatu Pendekatan. Strategis dengan Orientasi Global (Edisi Ke-2 Jilid 1 dan 2). Jakarta: Erlangga

Berman, Berry, dan Joel R Evans. (1995). Retail Management : A Sreategic Approach (6th Ed). New Jersey: Prantice Hall.

Dunne, Patric M. dan Robert F. Lusch. (2005). Retailing (5th Ed.). Ohio:South Western, A. Division of Thomson.

Euis, S .(2008). “Analisis Industri Ritel Di Indonesia” Jurnal Bisnis dan Ekonomi (JBE), September 2008, Hal. 128 - 142 Vol. 15, No.2 ISSN: 1412-3126 Fakultas Ekonomi Universitas Stikubank Semarang. http://www.academia.edu/5188327/ANALISIS_INDUSTRI_RITEL_DI_I NDONESIA_Oleh_Euis_Soliha_Fakultas_Ekonomi_Universitas_Stikuban k_Semarang

Fatimah, M.H. (2017). "Pengaruh Price discount, Bonus pack dan In-Store display terhadap keputusan Impulse buying pada Janu Putra Swalayan Jogjakarta”. Fakultas Ekonomi Universitas PGRI Yogyakarta. repository.upy.ac.id/1314/1/Artikel.pdf

Ghozali, Imam. (2011). Aplikasi Analisis Multivariate Dengan Program IBM. SPSS 19 (Edisi Ke-5). Semarang: Universitas Diponegoro.

Hidayati, A. dan Seno, A.H.D. (2016) "Pengaruh Point Of Purchase, Discount dan Store Atmosphere terhadap Impulse Buying Konsumen”. Fakultas Ilmu Sosial dan Ilmu Politik, Universitas Diponegoro. http://ejournal3.undip.ac.id/index.php/jiab/article/download/13515/13070 
Kotler, Philip. (2000). Manajemen Pemasaran (Edisi Milenium). Jakarta: Prehallindo.

Kotler, Philip, dan Gary Armstrong. (2001). Prinsip- Prinsip Pemasaran (Edisi Ke-8 Jilid 1). Jakarta: Erlangga.

Kotler, Philip, dan Kevin Keller. (2009). Manajemen Pemasaran (Edisi Ke-13 Jilid 2). Jakarta: Erlangga.

Levy, Michael, dan Barton A. Weitz. (2009). Retailing Management. (7th Ed). New York : McGraw-Hill Irwin.

Manggiasih, F.P., Widiartanto dan Prabawani, B. (2015). "Pengaruh discount, Merchandising, dan Hedonic shopping motives terhadap perilaku Impulse buying” Fakultas Ilmu Sosial dan Ilmu Politik, Universitas Diponegoro. http://ejournal3.undip.ac.id/index.php/jiab/article/download/9286/9016

Mowen, John C. dan Michael Minor. (2001). Perilaku Konsumen (Edisi Ke-5 Jilid 2). Jakarta:Penerbit Erlangga.

Raharjo, R.H. (2015). “Analisis Pengaruh Keberadaan Minimarket Modern Terhadap Kelangsungan Usaha Toko Kelontong Di Sekitarnya” Fakultas Ekonomika dan Bisnis atau Ilmu Ekonomi dan Studi Pembangun, Universitas Diponegoro. http://eprints.undip.ac.id/46533/1/06_RAHARJO.pdf

Sari D.A.T. dan Suryani, A. (2014). "Pengaruh Merchandising, Promosi dan Atmospher toko terhadap Impulse buying” E-jurnal Manajemen Unud. https://ojs.unud.ac.id/index.php/Manajemen/article/view/7074

Schiffman, Leon G. dan Leslie L. Kanuk. (2004). Consumer Behavior (8th Ed). New Jersey: Perason Prestice Hall. 
Setyasih, D.A. (2017). “Analisa pengaruh Price discount, Bonus pack, dan Instore display terhadap keputuhan Impulse buying behaviour konsumen pada Swalayan Kembang Mas Grabak Kota Magelang”. Fakultas Ekonomi Universitas PGRI Yogyakarta. repository.upy.ac.id/1301/1/Artikel.pdf

Shimp, Terence A. (2000). Periklanan Promosi: Aspek Tambahan Komunikasi. Pemasaran Terpadu (Edisi Ke-5 Jilid 2). Jakarta: Erlangga.

Sugiyono. (2010). Metode Penelitian Kuantitatfi Kualitatif dan R\&B. Bandung: Alfabeta.

Swastha, Basu dan Irawan. (2003). Manajemen Pemasaran Moderen (Edisi Ke-2). Jogjakarta: Liberty

Utami, Christina Whidya. (2010). Manajemen Ritel: Strategi dan Implementasi Operasional Bisnis Ritel Moderen Di Indonesia (Edisi Ke-2). Jakarta: Salemba Empat

Website

https://ekbis.sindonews.com/topic/5550/asosiasi-pengusaha-ritel-indonesia aprindo/ Diakses pada minggu, 2 April 2017 pukul 19.19 WIB.

www.marketing.co.id Diakses pada minggu, 2 April 2017 pukul 14.09 WIB www.indomaret.co.id Diakses pada Minggu, 2 April 2017 pukul 15.09 WIB (www.skyscrapercity.com) Diakses pada Minggu, 2 April 2017 pukul 15.09 WIB 